\title{
ポスターセッション
}

アポ蛋白測定の臨床的意義

\section{冠動脈狭窄度に対するアポリポ蛋白および脂質との 組み合わせ指標の意義*}

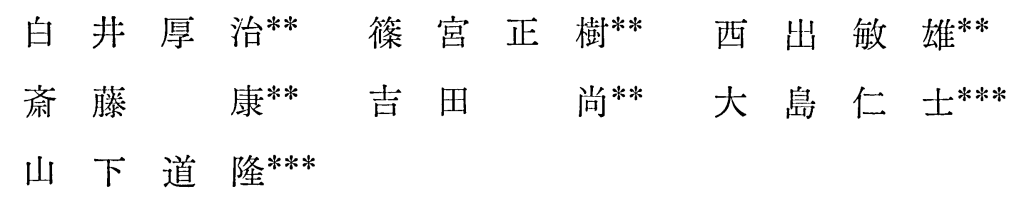

\section{I. はじめに}

近年, 血中アポリポ蛋白の測定が一元免疫拡散 法の普及によって，簡便に测定されるようにな $り^{1)}$, 従来の脂質值の測定で得られる情報に加え て, 新たな病態解析が可能となってきた. 冠動脈 硬化症の発症と進展度は従来より, 低比重りポタ ンパク (LDL), 中間型リポ蛋白 (IDL) と相関し, 一方高比重リポ蛋白 (HDL) とは逆相関すること が疫学的調查から報告されている2). 今回われわ れは虚血性心疾患患者で冠動脈造影を施行した症 例の冠動脈硬化度と血清脂質およびアポ蛋白との 関係をあきらかにし，さらにその組み合わせによ って有益な情報が得られる可能性を検討したので 報告する。

\section{II. 対象と方法}

対象者は, 冠動脈狭窄が疑われた症例で冠動脈 撮影を施行した 113 名 (男83例, 女30例) である. 狭心痛13例, 心筋梗塞41例, それ以外で心電図上, 虚血性変化を認め胸痛を訴えたもの59例. 平均年 齢は男性 $57 \pm 9$ 歳, 女性 $53 \pm 9$ 歳であった。

冠動脈撮影は, Judkins らの方法で行い, 左冠動

* 1986 年 1 月, 日本動脈硬化学会 昭和 60 年度冬季 大会において発表

* 千葉大学医学部第二内科

*** 松戸市立病院内科
脈 5 方向, 右冠動脈を 2 方向にて, シネアンジオ グラフィーを施行した.

冠動脈狭窄度は, 以下のごとくに score 化して 表現した. 各枝は American Heart Association 分 類をし, 各分節で狭窄なし 0 点, $25 \%$ 以下の狭 窄 1 点, $26 \sim 50 \%$ 狭窄 2 点, $51 \sim 75 \%$ 狭窄 3 点, 76 99\% 狭窄 4 点, 完全閉塞 5 点としその合計 を狭窄スコアーとした。

血清リポ蛋白測定は, ベックマン Lp-Ti ロー ターを用いて分画し, 酵素法で測定した ${ }^{3)}$.アポリ ポ蛋白 A-I, B は, single radial immunodiffusion 法のアポ蛋白測定キット（第一化学薬品株式会社 製）を用いて測定した.

\section{III. 結果と考察}

\section{1. 冠動脈狭窄分枝数と狭窄スコア (Fig. 1)}

$75 \%$ の有意狭窄分枝数で 表現した冠動脈狭窄 分枝数と狭窄スコアとの間には, 順位相関係数 +0.91 の有意正相関がみられ, 今回算出した狭窄 スコアは, 臨床的重症度を表現しているものと考 えられた。

\section{2. 狭窄スコアと血清脂質, およびアポ蛋白}

今回対象となった虚血性心疾患患者 (IHD) の 血清脂質レベルと正常対照者との比較検討成績を Table 1 に示した. IHD では, 総コレステロール 值は有意に高く, リポ蛋白分画では VLDL 画分 のコレステロール值と中性脂肪值が有意に高かっ 
動脈硬化 Vol.14 No.6 February 1987

た. LDL コレステロールは，高い傾向を示した が有意ではなかった。

次に IHD 患者と高脂血症型別に分離し，それ

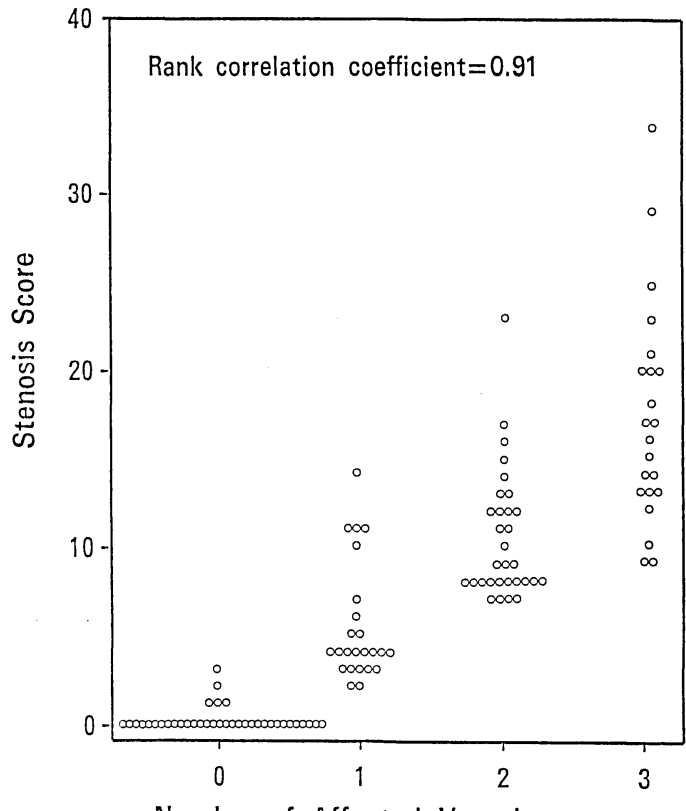

Number of Affected Vesseles

Fig. 1 Number of affected coronary arteries and stenosis score.
と狭窄スコアとの関係を検討し Table 2 に示した. 血清脂質正常群に比べ，IIb 型では狭窄スコアが 有意に高值を示した。

一方, IIa 型では正脂血症群に比べて狭窄スコ アは高い傾向がみられたが有意差はなく，IV 型 でも差がみられなかった. IIa 群とIIb 群とは LDL コレステロール值は，ほぼ同等であり， VLDL コレステロールは，それ自身の risk 性は 少なく，LDL が高值である時に冠動脈硬化を進 展させる因子として重要であることを推測させた。

このように，高脂血症の病型の違いによって狭 窄スコアに差がみられたことは，脂質值が冠動脈

Table 1 Lipoprotein lipid profiles in IHD patients

\begin{tabular}{lcrl}
\hline & $\begin{array}{c}\text { Normal } \\
\text { control } \\
\mathrm{n}=52\end{array}$ & $\begin{array}{c}\text { IHD } \\
\text { patients } \\
\mathrm{n}=113\end{array}$ & $\begin{array}{c}\text { Statistical } \\
\text { analysis }\end{array}$ \\
\hline T. Cholesterol & $182 \pm 42$ & $220 \pm 44$ & $\mathrm{p}<0.05$ \\
VLDL & $23 \pm 10$ & $47 \pm 26$ & $\mathrm{p}<0.01$ \\
LDL & $111 \pm 29$ & $127 \pm 32$ & N.S. \\
HDL & $52 \pm 10$ & $48 \pm 10$ & N.S. \\
Triglyceride & $132 \pm 51$ & $168 \pm 29$ & $\mathrm{p}<0.05$ \\
VLDL & $80 \pm 45$ & $108 \pm 72$ & N.S. \\
LDL & $26 \pm 8$ & $39 \pm 21$ & N.S. \\
HDL & $26 \pm 8$ & $26 \pm 11$ & N.S. \\
\hline
\end{tabular}

mean $\pm \mathrm{SD}(\mathrm{mg} / \mathrm{d} l)$

Table 2 Coronary artery stenosis scores and apolipoproteins in various lipoprotein disorders of ishemic heart disease

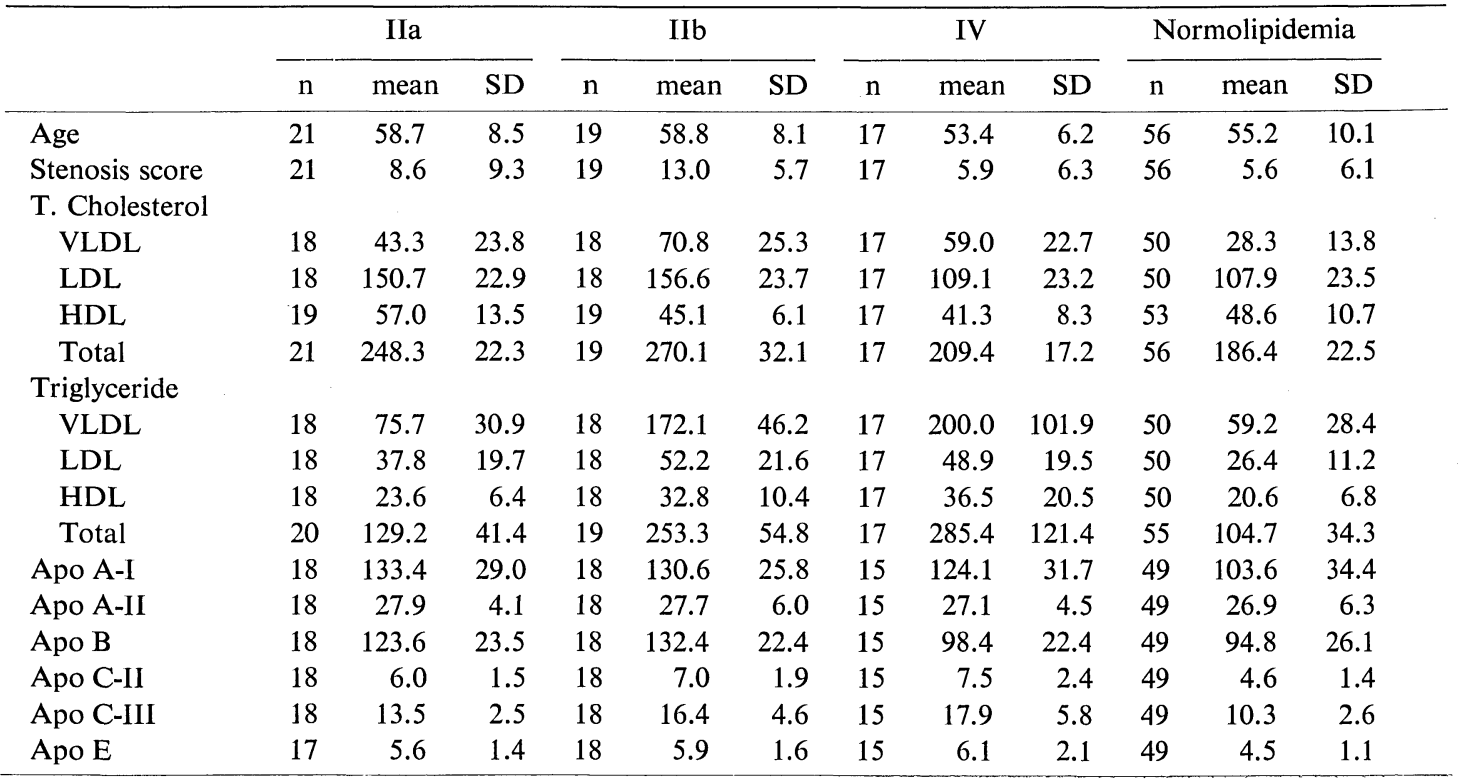

$(\mathrm{mg} / \mathrm{d} l)$ 
Table 3 Lipoprotein lipids or apolipoproteins, and coronary artery stenosis score in Type IIa

$\mathrm{n}=21$

\begin{tabular}{lccc}
\hline \multicolumn{1}{c}{ Mean score } & $\begin{array}{c}\text { Low score } \\
4.3 \pm 2.1\end{array}$ & $\begin{array}{c}\text { High score } \\
17.2 \pm 4.7\end{array}$ & $\begin{array}{c}\text { Statistical } \\
\text { analysis }\end{array}$ \\
\hline T. Cholesterol & $258 \pm 24$ & $243 \pm 21$ & N.S. \\
Triglyceride & $127 \pm 34$ & $135 \pm 42$ & N.S. \\
VLDL-C & $49 \pm 27$ & $43 \pm 26$ & N.S. \\
LDL-C & $152 \pm 23$ & $154 \pm 34$ & N.S. \\
HDL-C & $60 \pm 15$ & $53 \pm 5$ & N.S. \\
Apo A-I & $137 \pm 24$ & $123 \pm 25$ & N.S. \\
Apo B & $132 \pm 22$ & $122 \pm 31$ & N.S. \\
TC/HDL-C & $4.50 \pm 0.75$ & $4.66 \pm 0.28$ & N.S. \\
LDL-C/HDL-C & $2.65 \pm 0.65$ & $2.86 \pm 0.36$ & N.S. \\
LDL-C/Apo B & $1.09 \pm 0.19$ & $1.50 \pm 0.26$ & $\mathrm{p}<0.01$ \\
LDL-C/Apo A-I & $0.98 \pm 0.10$ & $1.37 \pm 0.32$ & $\mathrm{p}<0.01$ \\
Apo B/Apo A-I & $0.87 \pm 0.06$ & $0.99 \pm 0.05$ & $\mathrm{p}<0.01$ \\
\hline
\end{tabular}

mean $\pm \mathrm{SD}(\mathrm{mg} / \mathrm{d} l)$

硬化症の進展を予測する上で重要な因子のひとつ であることを示している。

次に高脂血症の病態の中でさらに狭窄度の差を あきらかに予測しうる血中因子について検討した. 高脂血症 IIa において狭窄度を高度群 (high score) と低值群 (low score) とに分け脂質值, リポ蛋白 分画脂質およびアポ蛋白について検討した結果を Table 3 に示した.

Low score 群 (平均 $4.3 \pm 2.1$ ) と High score 群 (17.2 \pm 4.7$)$ 間では, 脂質, アポ蛋白はともに有意 差はなかった。 そこで，それらの組み合わせによ る指標について検討した. Table 3 に示したごと く TC/HDL-C, LDL-C/HDL-C はともに差がみら れなかった。 しかし LDL-C/Apo B, LDL-C/Apo A-I, Apo B/Apo A-I は high score 群では low score 群に比べ有意に高值を示した.

LDL-C/Apo B が高いことは, リポ蛋白の側か ら考えるとコレステロール含量当たりの Apo Bが 少ないことを意味し, LDL-レセプターへの結合 能が低く，異化が悪い指標とも思われるが，さら に，その意義は検討されなければならない．Apo A-I は HDL の主要アポ蛋白で, これが高值であ
るほど anti-atherogenic と考えられ LDL-C/Apo A-I, Apo B/Apo A-I の比によって, より一層区

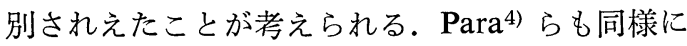
冠動脈撮影所見と Apo A-I/Apo B がもっともよ く相関することを報告している。このように，リ ポ蛋白とアポ蛋白，およびアポ蛋白同志の組み合 わせによって，冠動脈狭窄の程度が推定しうるこ とは，冠動脈狭窄に及ぼすリポ蛋白とアポ蛋白の 代謝の重要性が，再確認されたものと思われる.

\section{IV. まとめ}

1. 虚血性心疾患患者 113 名において冠動脈撮 影を行い，狭窄スコアを算出した. 高脂血症群で は, IIb 型 $>$ IIa 型 $>$ IV 型の順に狭窄スコアが高 かった。

2. IIa 型において，狭窄スコア高值群と低值 群を比較すると, 脂質值, アポ蛋白值については 差がみられなかった。しかし，LDL-C/apo B, LDL-C/Apo A-I, Apo B/Apo A-I 比は狭窄スコア 高值群で有意に高值を示した，以上より，リポ蛋 白脂質および，アポ蛋白の測定は，組み合わせる ことによって, 冠動脈狭窄度を high score と low score とに推定しうることが示唆された.

\section{文献}

1) Goto, Y., et al.: Determination by the SRID method of normal values of serum apolipoproteins J. Clin. Biochem. Nutr., 1: 73-88 (1986).

2) McGill, H. C.: Persistent problems in the pathogenesis of atherosclerosis; Arteriosclerosis, 4: 443451 (1984).

3) Bronzert, J. J. and Brewen, H. B.: New micro method for measuring cholesterol in plasma lipoprotein fractions. Clin. Chem., 23: 2089-2098 (1977).

4) Para, H., et al.: Lipoproteins, apolipoproteins and coronary artery disease assessed by coronary arteriography, in Latent Dyslipoproteinemias and Atherosclerosis edited by J. Le. Gennes. Raven Press, New York, 1984, p. 187. 


\title{
Summary
}

\section{Lipoprotein Lipids, Apolipoproteins and their Combinational Index in Coronary Artery Disease Assessed by Coronary Angiography}

\author{
Kohji Shirai*, Masaki ShinomiYa*, Toshio Nishide*, Yasushi SAIto*, \\ Sho Yoshida*, Hitoshi Ooshima** and Michitaka Yamashita** \\ *The Second Department of Internal Medicine, School of Medicine, Chiba University \\ ** Matsudo Municipal Hospital
}

The levels of serum lipoproteins and apolipoprotein in 113 peoples undertaking coronary angiography were examined, and their correlation between the severity of coronary stenosis were evaluated. Stenosis score caliculated from angiography were higher in IIb $>$ IIa $>$ IV hyperlipoproteinemia. In type IIa, the stenosis scores were not correlated with each levels of lipoprotein cholesterol, and apo A-I and apo B. But the ratios of LDL-C/apo B, LDL-C/apo A-I and apo B/ apo A-I were significantly correlated with stenosis scores. These results suggest that the combination of apo B, apo A-I and LDL-C were useful indicator for forcasting the degree of coronary stenosis.

Key words: apo A-I, apo B, LDL-cholesterol, coronary angiography, stenosis score. 